\title{
Psychological contract breach and organizational cynicism and commitment among self-initiated expatriates vs. host country nationals in the Chinese and Malaysian transnational education sector
}

\author{
Émilie Lapointe $^{1}\left(\mathbb{D} \cdot\right.$ Christian Vandenberghe $^{2}$ (D) Shea X. Fan $^{3}$ (D)
}

Published online: 15 July 2020

(C) The Author(s) 2020

\begin{abstract}
In today's global economy, self-initiated expatriates (SIEs) and host country nationals (HCNs) both represent critical human resources for organizations operating globally. Yet, because these two groups of employees have been studied separately, little is known about how SIEs' and HCNs' perceptions of, and attitudes towards the organization compare and diverge (vs. converge) in terms of implications for human resource management. This study aims to contribute to fill this gap by examining psychological contract breach, organizational cynicism, and organizational commitment components (i.e., affective, normative, and continuance) among a sample of 156 SIEs and HCNs working in the Chinese and Malaysian transnational education sector. Using a one-year time-lagged study, we found that compared to HCNs, SIEs experienced more organizational cynicism and less affective, normative, and continuance commitment. Moreover, the breach-organizational cynicism relationship was stronger (i.e., more positive) among SIEs than HCNs. The indirect relationships between breach and affective and continuance commitment, as mediated by organizational cynicism, were also stronger (i.e., more negative) among SIEs than HCNs. Implications for human resource management are discussed under the lens of Conservation of Resources theory.
\end{abstract}

Keywords Self-initiated expatriates $\cdot$ Host country nationals $\cdot$ Psychological contract breach · Organizational cynicism · Organizational commitment · China and Malaysia

In a context of globalization, many organizations, from established multinational corporations to smaller enterprises and international joint ventures, seek to attract international talents (Collings, Scullion, \& Morley, 2007). Along with those, talented

Émilie Lapointe

emilie.lapointe@bi.no

Extended author information available on the last page of the article 
individuals seek employment opportunities worldwide (Haslberger \& Vaiman, 2013; Tharenou, 2013). The workforce in many organizations is, as a result, becoming more diverse. Among others, self-initiated expatriates (i.e., individuals who seek employment outside of their home country on a self-initiated basis and do not aim to settle permanently in the host country; SIEs) have emerged as a central group of employees (Altman \& Baruch, 2013; Andersen, 2019; Selmer, Andersen, \& Cerdin, 2017). SIEs are increasingly working side-by-side with local employees (i.e., host country nationals; HCNs) (Kraimer, Takeuchi, \& Frese, 2014; Singh, Pereira, Mellahi, \& Collings, 2019). Yet, very little research has jointly studied these two groups of employees. ${ }^{1}$ This is an important research avenue because SIEs and HCNs are fundamentally different. They differ from one another, not only based on national origin but also in terms of the challenges they face and the resources they need. These fundamental differences likely shape SIEs' and HCNs' perceptions of, and attitudes towards the organization, as well as their implications. They may also point out the necessity, for organizations, to adjust human resource management practices to the needs of each group. This paper aims to address this research avenue by examining how SIEs and HCNs view and relate to their organization.

Drawing on principles from Conservation of Resources (COR) theory (Hobfoll, 1989), we contend that, as a group of employees, SIEs are more likely to suffer from resource depletion or, in other words, to lack the resources they need, than HCNs. This should occur because SIEs are less familiar with the host country and the host organization than HCNs, hence see the resources they possess being highly solicited and have to acquire others, which they do not possess, to function effectively. This key difference should make SIEs more likely than HCNs to hold negative views and attitudes towards the organization (and less likely to hold positive ones), especially those views and attitudes that are known to be influenced by employees' resources. Given that previous COR research indicates that employees' resources affect and shape psychological contract breach perceptions (Robinson \& Morrison, 2000), organizational cynicism (Dean, Brandes, \& Dharwadkar, 1998), and organizational commitment (Meyer \& Allen, 1991; Meyer \& Herscovitch, 2001; Byrne \& Hochwarter, 2008; Hobfoll \& Shirom, 2001; Kiazad, Seibert, \& Kraimer, 2014; Lapointe et al., 2013; Lapointe, Vandenberghe, \& Boudrias, 2011), we focus on these key perceptions and attitudes in our study. We argue that, due to heightened resource depletion, SIEs, compared to HCNs, will report more psychological contract breach perceptions and organizational cynicism, and less affective, normative, and continuance commitment. Extending our COR theory reasoning to the examination of the relationships between our focal variables, we further argue that psychological contract breach will lead to increased organizational cynicism and, through organizational cynicism, to lower affective, normative, and continuance commitment among SIEs vs. HCNs.

This paper goes beyond previous research, which focused on either SIEs or HCNs (e.g., Hitotsuyanagi-Hansel, Froese, \& Pak, 2016; Makkonen, 2017). It reveals a more complete and nuanced understanding of how different groups of employees perceive

\footnotetext{
${ }^{1}$ In this paper, we will use the word 'group' to refer to employees from the host country (i.e., HCNs) versus employees who do not originate from the host country but moved in the host country by themselves for employment purposes and without the intention of settling permanently in the host country (SIEs) (see Altman \& Baruch, 2013; Selmer et al., 2017).
} 
and relate to their organization. We directly compared SIEs and HCNs on key variables and examined how group membership (SIE or HCN) shapes the relationships among variables. This twofold approach enables us to fully seize the implications that differences between SIEs and HCNs have for research and practice. By adopting a COR theory framework, we put at the forefront the notion of 'resource'. We show that resources are closely tied to employees' group membership (SIE vs. HCN). We also show that COR theory can help understand how to effectively manage the two groups that are SIEs and HCNs (Hobfoll, Halbesleben, Neveu, \& Westman, 2018; Kraimer et al., 2014) by suggesting that they may vary in the extent to which they experience resource depletion. Thus, this paper provides insights into how, in an increasingly globalized work context, organizations can better manage their employees (Kraimer et al., 2014). Such an endeavor is particularly important in the Asia Pacific region. As shown by recent studies (Froese, 2012; Halim, Bakar, \& Mohamad, 2014; Makkonen, 2017; Richardson \& Ng, 2019; Selmer \& Lauring, 2014; Tang, Chang, \& Cheng, 2017), SIEs represent an important group of employees for organizations located in this region. They are, in fact, increasingly considered as part of local organizations' staffing strategy (Makkonen, 2016, 2017). Yet, Asia Pacific countries such as China and Malaysia are known to pose great challenges to organizations seeking to attract and retain global talented employees (Brookfield Global Relocation Services, 2016; Harvey, Speier, \& Novecevic, 2001; Yeung, Warner, \& Rowley, 2008). Within these countries, human resource management challenges associated with employee attraction and retention are even more salient in the transnational education sector (Hassan \& Hashim, 2011; Lauring \& Selmer, 2014; Ramalu, Subramaniam, \& Nadarajah, 2017; Richardson \& Wong, 2018). To add relevance to our study, we therefore draw on a sample of SIEs and HCNs working in the Chinese and Malaysian transnational education sector. We also adopted a one-year time-lagged design to improve over previous research in the field, which has been mostly cross-sectional (see Cascio, 2012; Kraimer, Bolino, \& Mead, 2016; Shaffer, Kraimer, Chen, \& Bolino, 2012).

\section{Theoretical background}

\section{An overview of COR theory}

COR theory revolves, as mentioned above, around the notion of 'resource'. Resources include 'object resources (e.g., car, tools for work), condition resources (e.g., employment, tenure, seniority), personal resources (e.g., key skills and personal traits such as self-efficacy and optimism), and energy resources (e.g., credit, knowledge, money)' (Hobfoll et al., 2018, p. 105). Resources are, all in all, varied but, importantly, they all help individuals achieve their goals (Halbesleben, Neveu, Paustian-Underdahl, \& Westman, 2014). It is this essential property that makes a specific object, condition, etc., a resource (Halbesleben et al., 2014). COR theory also distinguishes between resource loss and resource gain. Resource loss occurs when resources are subtracted from individuals' resource pool and resource gain occurs when resources are added to individuals' resource pool (Halbesleben et al., 2014). Importantly, COR theory stipulates that resource loss is perceived as more salient by individuals than resource gain (Halbesleben et al., 2014). Of similar importance, COR theory stipulates that 
individuals must invest resources to gain resources and protect themselves from losing resources or to recover from resource loss (Halbesleben et al., 2014). When individuals do not possess enough resources, gaining new resources can prevent them from entering into a resource loss spiral (i.e., losing further resources over time) whereas, when individuals have enough resources, gaining new resources can further strengthen or help expand their existing resource pool (Halbesleben et al., 2014). Taken together, these tenets highlight the fact that at least some resources are needed for individuals to function effectively. They also show that resource depletion, defined as a state in which individuals lack the resources they need, can be particularly debilitating (Halbesleben et al., 2014; Hobfoll, 1989; Hobfoll et al., 2018). In this regard, Hobfoll and colleagues (Hobfoll, 1989; Hobfoll et al., 2018) specify that environmental and contextual circumstances are critical to understand resource depletion and its deleterious consequences.

\section{COR theory and SIEs vs. HCNs}

A critical difference between SIEs and HCNs is that, for HCNs, the host country is a familiar environment while, for SIEs, it is a foreign environment. This difference should make SIEs more likely to experience resource depletion than HCNs, for two main reasons. First, SIEs should experience heightened resource depletion compared to $\mathrm{HCNs}$ because their resources should be more solicited in the host country than those of HCNs. Indeed, when individuals move beyond national or cultural borders, they need, for instance, more personal resources such as self-efficacy, flexibility, openness, tolerance of ambiguity and emotional sensitivity to adjust to the host country environment (Lazarova, Westman, \& Shaffer, 2010; Zhu, Wanberg, Harrison, \& Diehn, 2016). Given that they move on their own, SIEs also need more energy resources such as time and physical energy (Ten Brummelhuis \& Bakker, 2012 ) to 'learn the ropes' independently or with very limited support (McDonnell \& Scullion, 2013). In contrast, HCNs navigate in an environment in which they are socially and culturally embedded, hence they are less likely to see their resources being solicited to deal with similar challenges and, if they do, they should more easily overcome obstacles and achieve their goals (Reiche, 2007; Tarique, Schuler, \& Gong, 2006; Vance, Vaiman, \& Andersen, 2009). Second, there should be a variety of resources that SIEs do not possess and need to acquire. To function effectively in the host country, they need to acquire local language skills, knowledge, and networks (Altman \& Baruch, 2013; Lee, 2005; Suutari \& Brewster, 2000; see also Caligiuri \& Lazarova, 2002; Kraimer, Wayne, \& Jaworski, 2001). Similarly, in the work context, SIEs must acquire various resources to perform their tasks and build and maintain quality relationships with colleagues, clients, and other important stakeholders (Shen \& Kram, 2011). HCNs, due to their familiarity with the host country and the host organization, may not have to tackle this learning curve (Shen \& Kram, 2011).

To summarize, SIEs should be more likely to experience resource depletion than HCNs because (a) the resources they possess should be more solicited and (b) they will have to acquire new resources to function effectively. The heightened state of resource 
depletion among SIEs (vs. HCNs) should adversely impact the perceptions and attitudes typically influenced by employees' resources. More specifically, the deleterious effect of resource depletion should translate into stronger perceptions of psychological contract breach, increased organizational cynicism, and lower organizational commitment among SIEs (vs. HCNs) (Byrne \& Hochwarter, 2008; Hobfoll \& Shirom, 2001; Kiazad et al., 2014; Lapointe et al., 2013; Lapointe et al., 2011). Employees' group membership (SIE vs. HCN) should also represent a significant moderator of the relations among contract breach, organizational cynicism, and organizational commitment. We further develop our reasoning around these ideas in the next section.

\section{Hypothesis development}

\section{Perceptions and attitudes among SIEs vs. HCNs}

\section{Psychological contract breach}

Psychological contracts capture employees' beliefs about what they are entitled to receive, or should receive, based on perceived promises made by the organization and on normative expectations (Morrison \& Robinson, 1997; Rousseau, Hansen, \& Tomprou, 2018). Perceptions of unmet promises and expectations lead employees to experience psychological contract breach, that is to view that the organization failed to fulfill its obligations towards them (Morrison \& Robinson, 1997; Rousseau et al., 2018). Psychological contract breach reflects employees' cognitive judgment and evaluation of the organization's obligations, hence may or may not align with the promises explicitly made by the organization (Coyle-Shapiro, Costa, Doden, \& Chang, 2019; Rousseau et al., 2018). As we will argue below, SIEs should be more likely to report breach than HCNs.

Previous research shows that expatriates experience heightened uncertainty and ambiguity in the host country and view the organization as an essential source of help and support (McNulty, 2013). Stated otherwise, expatriates experience resource depletion and expect that the organization will provide the necessary resources to overcome the challenges they face and restore their resource pool (Halbesleben et al., 2014). However, their organization might not be able to meet these expectations. Usually, when assigning corporate expatriates for international assignments, organizations include resources such as settling-in assistance, well-being support, language training, personal and family safety as well as work-related assistance in expatriates' package (McDonnell \& Scullion, 2013; see also O’Donohue, Hutchings, \& Hansen, 2018; Perera, Chew, \& Nielsen, 2017). These resources are provided to expatriates to help them function effectively. Yet, because SIEs moved to the host country on their own initiative (Selmer et al., 2017), organizations might not have a systematic and comprehensive plan to provide them with these resources (McDonnell \& Scullion, 2013). The organizations in which SIEs work might not have sufficient experience or knowledge to meet the resource needs of expatriates (Froese, 2012). Thus, SIEs, a specific type of expatriates, are likely to perceive a gap between what they expected from the organization in terms of resources and what they actually receive. HCNs, because they already live in the host country and possess the resources needed to navigate in this 
environment, are less likely to perceive this gap. It follows that SIEs should report stronger breach perceptions than HCNs.

Hypothesis 1a. SIEs will report more psychological contract breach than HCNs.

\section{Organizational cynicism}

Organizational cynicism reflects one's negative attitude toward the organization (Dean et al., 1998). It comprises cognitions, affects, and behavioral tendencies. The cognitive component of organizational cynicism captures the idea that cynical employees think that their organization lacks integrity, sincerity, honesty, and fairness (Andersson, 1996; Dean et al., 1998; Wilkerson, Evans, \& Davis, 2008). The affective component of organizational cynicism captures the idea that cynical employees experience negative affective states (e.g., frustration, anger, inequity) when thinking of their organization (Abraham, 2000; Andersson, 1996; Dean et al., 1998). The behavioral component of organizational cynicism reflects the fact that cynical employees engage in behaviors that are consistent with the above negative beliefs and affects (e.g., bad mouthing the organization; Andersson, 1996; Wilkerson et al., 2008). Researchers usually focus on one or more of the above components, depending on the goal of their study (e.g., Gkorezis, Georgiou, \& Theodorou, 2018; Johnson \& O'Leary-Kelly, 2003). In this paper, we focus on the affective component of organizational cynicism, which reflects employees' emotional responses. This is because the affective component of organizational cynicism is most likely to be affected by resource depletion, as is illustrated in the literature on emotional exhaustion (Crawford, LePine, \& Rich, 2010). Thus, it is particularly relevant within our COR theory framework.

We contend that SIEs are more likely to report organizational cynicism than HCNs. As previously explained, SIEs are likely to experience a higher level of resource depletion than HCNs; therefore, they need a strategy to deal with this lack of resources and to gain a sense of balance. Organizational cynicism, because it represents a selfdefensive and low-investment coping strategy (Abraham, 2000; Byrne \& Hochwarter, 2008; Hobfoll \& Shirom, 2001), can help SIEs achieve this goal at a minimal cost in terms of resources. Indeed, organizational cynicism enables individuals to cope with unpleasant experiences without expending much personal resources by way of forming negative affects towards the organization (e.g., frustration, anger, and inequity). These negative affects create a 'disconnect' between individuals and the organization, which shield them against future disappointments (Byrne \& Hochwarter, 2008). Using organizational cynicism, SIEs can therefore distance themselves from the organization while also gaining some psychological comfort in dealing with the challenges they face, without exerting the few resources they have left. ${ }^{2}$ Stated otherwise, organizational cynicism helps SIEs to maintain a certain sense of balance while also avoiding further resource loss and, potentially, entering a resource loss spiral (Halbesleben et al., 2014; Hobfoll et al., 2018). Following these arguments, we hypothesize that SIEs will report more organizational cynicism than HCNs.

\footnotetext{
${ }^{2}$ For research on the use of self-defensive strategies among expatriates, see Richards (1996) and Shaffer and Harrison (1998).
} 
Hypothesis $1 b$. SIEs will report more organizational cynicism than HCNs.

\section{Organizational commitment}

Meyer and Allen's (1991; see also Meyer \& Herscovitch, 2001) three-component model is the most widely used model of commitment. It comprises affective commitment, i.e., employees' emotional attachment to the organization, normative commitment, i.e., employees' feeling of moral obligation toward the organization, and continuance commitment, i.e., employees' sense that organizational membership provides valuable benefits, such as good job conditions.

Affective and normative commitment share some common grounds. To build and maintain affective and normative commitment, individuals need to invest resources (e.g., time and physical energy) in the organization. Indeed, affective commitment develops, among other things, through personal involvement in the organization while normative commitment instills reciprocation towards the organization (Meyer \& Herscovitch, 2001). Furthermore, these commitments both lead individuals to demonstrate desirable and resource-consuming behavior such as citizenship behavior (Halbesleben, Harvey, \& Bolino, 2009; Meyer et al., 2002). Since SIEs are more likely to be at risk of resource depletion, they should be reluctant to expend extra resources building and maintaining strong affective and normative commitment. Indeed, they should focus on protecting and preserving their resources rather than expending them (Halbesleben et al., 2014; Hobfoll et al., 2018). SIEs should therefore report lower levels of affective and normative commitment than HCNs.

In contrast with affective and normative commitment, continuance commitment focuses on the instrumental benefits that organizational membership provides (Meyer \& Herscovitch, 2001). In this regard, one should note that SIEs and HCNs can receive similar salaries and fringe benefits (Dowling, Festing, \& Engle, 2008). ${ }^{3}$ Also, recall that money represents a type of energy resource (Hobfoll et al., 2018). As mentioned earlier, SIEs may face more challenges because they navigate in a foreign environment. They may struggle to refill their resource pool and are highly vulnerable to further loss (Halbesleben et al., 2014). As a result, they may perceive the pay package provided by the organization as insufficient while HCNs may see it as appropriate (Dowling et al., 2008; Haslberger \& Vaiman, 2013). Because SIEs are more likely than HCNs to perceive an imbalance between the resources that they ought to have (here, the pay package) and the resources that they actually have, they should report lower continuance commitment than HCNs. Taken together, the above arguments regarding affective, normative, and continuance commitment lead to the following hypotheses.

Hypothesis 1c. SIEs will report less affective commitment than HCNs.

Hypothesis 1d. SIEs will report less normative commitment than HCNs.

\footnotetext{
${ }^{3}$ Note that the situation is different for assigned corporate expatriates, who receive substantially more generous pay packages than HCNs and SIEs (Dowling et al., 2008).
} 
Hypothesis 1e. SIEs will report less continuance commitment than HCNs.

\section{Employee group membership (SIE vs. HCN) as a moderator}

As argued above, heightened resource depletion among SIEs leads them to compare unfavorably to HCNs in terms of psychological contract breach, organizational cynicism, and affective, normative, and continuance commitment. Extending our COR theory reasoning, we now contend that the state of heightened resource depletion experienced by SIEs (vs. HCNs) will shape the relationships between these variables. Specifically, employee group membership (SIE vs. HCN) should moderate the relation of psychological contract breach to organizational commitment components, as mediated by organizational cynicism. The relations should be stronger among SIEs than HCNs. We develop our reasoning for this pattern of relations below.

Psychological contract breach is a negative, often surprising event that mobilizes individuals' resources (Conway, Guest, \& Trenberth, 2011; Kiazad et al., 2014; Lapointe et al., 2013). It triggers a cognitive process whereby employees try to make sense of what happened (Morrison amp; Robinson, 1997). As part of this cognitive sense-making process, employees try to understand the causes of the breach and assign responsibility for the breach (Morrison \& Robinson, 1997; Parzefall, 2011; Wong \& Weiner, 1981). Because the psychological contract is established between the organization and its employees and because SIEs are more likely to suffer from resource depletion than HCNs, SIEs should be more likely to blame the organization following a case of breach than HCNs (Morrison \& Robinson, 1997). Indeed, individuals who are more depleted from their resources are more likely to assign the responsibility of negative events such as psychological contract breach to other parties involved (here, the organization) than to themselves (Mayo \& Mallin, 2010; see also Taylor \& Fiske, 1978). Moreover, previous research suggests that it is specifically when the organization is seen as being at fault (i.e., as being blameworthy) that breach makes employees feel disillusioned and unlikely to place their future confidence in the organization, hence cynical towards the organization (Andersson, 1996; Dean et al., 1998; Johnson \& O'Leary-Kelly, 2003; Pfrombeck, Doden, Grote, \& Feierabend, 2020). Thus, SIEs should more readily attribute breach to, for instance, a lack of integrity on the part of the organization, than HCNs. Such attributions should make psychological contract breach more likely to translate into organizational cynicism among SIEs (vs. HCNs). This leads to the following hypothesis.

Hypothesis 2: Employee group membership (SIE vs. HCN) will moderate the relationship between psychological contract breach and organizational cynicism, such that this relationship is stronger (i.e., more positive) among SIEs than among HCNs.

Through organizational cynicism, breach should also lead to lowered affective, normative, and continuance commitment among SIEs compared to HCNs. Indeed, previous research on organizational cynicism highlighted the fact that it is broad in scope and generalizes from one object to another (Johnson \& O'Leary-Kelly, 2003). This suggests that organizational cynicism may represent a mechanism through which employees' perception of psychological contract breach and the specific attributions that 
accompany it, come to affect their commitment to the organization. That is, the experience of frustration that is elicited by breach and is the essence of the affective component of organizational cynicism should convey the negative effect of breach on employees' experience of their relationship with the organization, and, following our previous argument, this negative effect should be exacerbated among SIEs compared to HCNs. In other words, perceptions of psychological contract breach among SIEs should, through cynicism, lead to less affective, normative, and continuance commitment than among HCNs. This moderated mediation hypothesis extends on previous research showing that the affective component of organizational cynicism mediates the relationship between psychological contract breach and affective commitment (Johnson \& O'Leary-Kelly, 2003). It is summarized below.

Hypothesis 3: Employee group membership (SIE vs. HCN) will moderate the indirect relationships between psychological contract breach and (a) affective commitment, (b) normative commitment, and (c) continuance commitment (as mediated by organizational cynicism), such that these indirect relationships will be stronger (i.e., more negative) among SIEs than among HCNs.

\section{Method}

\section{Sample and procedure}

This study was conducted in the transnational education sector. Participants were recruited among the Chinese and Malaysian operations of a Western higher education institution. This institution offers formal tertiary degree programs and courses, as well as locally recognized courses and programs, on a variety of topics, including foreign languages, business management, and international communication. The two overseas operations are similar in size. Although the local context is considered, the Western organization applies the same general human resource management policies in these two operations. Importantly, the two operations recruit global talents independently instead of using corporate expatriates from the headquarters, i.e., they recruit individuals who seek jobs in China and Malaysia on their own rather than taking in expatriates assigned by the headquarters to fill positions. They also recruit local talents. Thus, their employees can be categorized as SIEs and HCNs (Suutari, Brewster, Makela, Dickmann, \& Tornikoski, 2018). Employees working in the two operations perform a variety of tasks, including teaching-related tasks, research-related tasks, and managerial and administrative tasks.

Following approval by the upper management of the two operations (i.e., in China and Malaysia), an email containing a link to the first survey (Time 1) was sent to all 1328 employees. The introductory page of the survey explained the purpose of the study and advised employees that participation was voluntary and that responses would be kept confidential. One year later, employees were invited by email to complete a second survey (Time 2). Psychological contract breach and sociodemographic information (i.e., group membership [SIE vs. HCN], age, gender, and organizational tenure) were assessed at Time 1, while organizational cynicism and organizational commitment components were measured at Time 2. This time lag enabled us to ensure that 
organizational cynicism and commitment had time to develop among participants, and that breach had time to show its effects on employees (see Chen \& Shaffer, 2017, for a similar reasoning). Using a time-lagged design is also consistent with COR theory, which suggests that conditions that mobilize individuals' resources (here, psychological contract breach) may take time to affect individuals (see Halbesleben et al., 2014, and Hobfoll et al., 2018, for discussions of COR theory and time).

A total of 464 employees provided full data for the first survey (218 employees from the Chinese operation and 246 employees from the Malaysian operation, for an overall response rate of 35\%). Matched data at Time 2 were obtained for 156 employees (71 employees from the Chinese operation and 85 employees from the Malaysian operation, corresponding to $34 \%$ of Time 1 responses). Note that, although relatively modest, the response rate and final sample size are comparable to that of similar studies and reflect the difficulty of collecting this type of data (Bhaskar-Shrinivas, Harrison, Shaffer, \& Luk, 2005; Tharenou, 2015; Yang, Wang, \& Su, 2006). Furthermore, results of attrition analyses (Goodman \& Blum, 1996) (available upon request) indicate that attrition is not predicted by the study variables. This suggests that data attrition across time was randomly distributed. In the overall sample, $42 \%$ of participants were SIEs, $51 \%$ were male, and $60 \%$ were 36 years old or older. In terms of tenure, $66 \%$ reported working for the organization (i.e., the overseas' operation in China or Malaysia) for 5 years or less.

\section{Measures}

Because English is the working language of all employees surveyed, the original English versions of the scales were used in this study. A 5-point Likert-type scale ranging from 1 (strongly disagree) to 5 (strongly agree) was used for all items except organizational cynicism items, for which the response scale is described below. For all scales, we referred to the 'organization' using the name of the overseas' operation in China (for employees based in China) or Malaysia (for employees based in Malaysia).

\section{Psychological contract breach}

Robinson and Morrison's (2000) 5-item scale was used to measure psychological contract breach (e.g., 'So far, [name of the overseas' operation] has done an excellent job of fulfilling its promises to me'; reversed item; $\alpha=.91$ ).

\section{Organizational cynicism}

As mentioned in the development of the study's hypotheses, we focused on the affective component of organizational cynicism. This component was measured using an adapted version of the 10-item scale reported by Johnson and O'Leary-Kelly (Johnson \& O'Leary-Kelly, 2003). Instead of using a semantic differential scale, we asked participants to report the extent to which they experienced a series of affective states (e.g. 'anxious', 'tense', or 'reassured' [reversed]) when thinking about their organization (i.e., the overseas' operation). Responses were rated on a Likert-type scale ranging from 1 (very slightly or not at all) to 5 (extremely). This response scale was preferred over the semantic differential scale following a pre-test with a subsample of participants who reported that the original response scale was confusing. More 
specifically, we sent the original Johnson and O'Leary-Kelly's (Johnson \& O'LearyKelly, 2003) measure to a subset of participants (including both SIEs and HCNs) and asked them to provide their comments on the clarity of the instructions, response scale, and items. All of them made negative comments about the clarity of the semantic differential scale. We then replaced the semantic differential scale by a Likert-type scale, like other researchers using this scale did (e.g., Morf, Bakker, \& Feierabend, 2019), and sent it back to the same subset of participants. Participants told us that this response format was much clearer. Thus, our decision to change the response scale was driven by the feedback we received from our target sample but is also consistent with recent research using this specific scale to measure the affective component of organizational cynicism. Note that, in Morf et al.'s (2019) case, just as in our case, the scale's internal reliability remained very good $(\alpha=.92)$ and its relationships with other variables remained consistent with what could be expected based on the literature.

\section{Organizational commitment}

Affective, normative, and continuance commitment were measured using Bentein, Vandenberg, Vandenberghe, and Stinglhamber's (2005) adapted version of Meyer, Allen, and Smith's (1993) scales. Affective (e.g., 'I feel like part of the family at [name of the overseas' operation]'; $\alpha=.95$ ) and normative (e.g., 'I think I would be guilty if I left [name of the overseas' operation] now'; $\alpha=.92$ ) commitment scales comprised six items, while continuance commitment (e.g., 'I would not leave [name of the overseas' operation] because of what I would stand to lose'; $\alpha=.88$ ) was assessed by three items. Note that, consistent with Powell and Meyer (2004), the measure of continuance commitment used in this study reflects commitment based on investments that would be sacrificed in case of ending the relationship with the organization.

\section{Control variables}

We controlled for gender, age and tenure, as previous research reported significant correlations between these demographics and one or more of the study's variables (e.g., Bal, De Lange, Jansen, \& Van Der Velde, 2008; Bentein et al., 2005; Byrne \& Hochwarter, 2008; Dulac, Coyle-Shapiro, Henderson, \& Wayne, 2008; Lorinkova \& Perry, 2017; Meyer, Stanley, Herscovitch, \& Topolnytsky, 2002; Vandenberghe, Panaccio, \& Ben Ayed, 2011). We also controlled for the operation to which participants were affiliated $(0=\mathrm{China}, 1=$ Malaysia) to ensure that the findings do not reflect operation-specific effects. Controlling for this variable also helps to ensure that findings are not influenced by the national origin of HCNs, which, in this study, can be Chinese or Malaysian, and truly reflect differences based on employee group membership (i.e., SIE vs. HCN).

\section{Results}

\section{Confirmatory factor analyses}

Mplus 6.12 (Muthen \& Muthen, 2011) and the maximum likelihood method of estimation were used for confirmatory factor analyses. The hypothesized 5-factor 
model yielded a reasonably good fit to the data: $\chi^{2}(265)=589.88, p<.001$, root mean square error of approximation $(\mathrm{RMSEA})=.09$, comparative fit index $(\mathrm{CFI})=.91$, Tucker-Lewis index $(\mathrm{TLI})=.90$, standardized root mean square residual $(\mathrm{SRMR})=.06$. Although the value for the RMSEA was rather large $(\geq .08)$, it should be interpreted with caution in light of the sample size. Indeed, the RMSEA tends to over-reject the true model (i.e., to be positively biased) in small samples $(N \leq 250$; Hu \& Bentler, 1999) and, hence, may be inflated in this study (Chen, Curran, Bollen, Kirby, \& Paxton, 2008; Kenny, Kaniskan, \& McCoach, 2015). The 5-factor model also proved superior to six 4-factor models combining (a) organizational cynicism with each commitment variable alternatively or (b) commitment variables on a two-by-two basis, a 3-factor model merging all commitment variables, a 2-factor model combining all Time 2 variables, and a 1 -factor model $\left(\Delta \chi^{2}=178.19\right.$ to $1656.24, \Delta d f=4$ to $10, p$ $<.001)$. Thus, the study's variables appear distinguishable.

Table 1 Descriptive statistics and intercorrelations for the study variables

\begin{tabular}{|c|c|c|c|c|c|c|c|c|c|c|c|}
\hline Variable & $M$ & $S D$ & 1 & 2 & 3 & 4 & 5 & 6 & 7 & 8 & 9 \\
\hline $\begin{array}{l}\text { 1. Psychological } \\
\text { contract } \\
\text { breach (T1) }\end{array}$ & 2.77 & 1.02 & $(.91)$ & & & & & & & & \\
\hline $\begin{array}{l}\text { 2. Employee } \\
\text { group } \\
\text { membership } \\
\text { (T1) }\end{array}$ & 0.42 & 0.49 & .03 & - & & & & & & & \\
\hline $\begin{array}{l}\text { 3. Organizational } \\
\text { cynicism (T2) }\end{array}$ & 2.76 & 0.86 & $.36 * * *$ & $.39 * * *$ & $(.92)$ & & & & & & \\
\hline $\begin{array}{l}\text { 4. Affective } \\
\text { commitment } \\
\text { (T2) }\end{array}$ & 3.52 & 1.08 & $-.28 * *$ & $-.38 * * *$ & $-.64 * * *$ & $(.95)$ & & & & & \\
\hline $\begin{array}{l}\text { 5. Normative } \\
\text { commitment } \\
\text { (T2) }\end{array}$ & 2.78 & 1.14 & -.09 & $-.32 * * *$ & $-.40 * * *$ & $.56^{* * * *}$ & $(.92)$ & & & & \\
\hline $\begin{array}{l}\text { 6. Continuance } \\
\text { commitment } \\
\text { (T2) }\end{array}$ & 2.75 & 1.17 & $-.27 * *$ & $-.31 * * *$ & $-.38 * * *$ & $.56 * * *$ & $.56 * * *$ & $(.88)$ & & & \\
\hline 7. Gender (T1) & 0.49 & 0.50 & .04 & $-.37 * * *$ & -.07 & $.15 \dagger$ & $.21 *$ & $.15 \dagger$ & - & & \\
\hline 8. Age (T1) & 0.60 & 0.49 & -.12 & $.37 * * *$ & .10 & .03 & -.04 & .01 & $-.29 * * *$ & - & \\
\hline 9. Tenure (T1) & 0.34 & 0.47 & -.00 & -.12 & -.08 & $.21^{*}$ & .03 & .11 & -.08 & $.24 * *$ & - \\
\hline $\begin{array}{l}\text { 10. Operation } \\
\text { (T1) }\end{array}$ & 0.54 & 0.50 & -.05 & $-.35^{* * *}$ & -.11 & $.15 \dagger$ & .11 & .12 & .11 & $.21 *$ & .10 \\
\hline
\end{tabular}

Note. Ns $=156-144 . \mathrm{T} 1=$ Time 1; T2 = Time 2. For Employee group membership: $0=$ host country national, $1=$ self-initiated expatriate; for Gender: $0=$ male, $1=$ female; for Age: $0=35$ years old or less, $1=36$ years old or older; for Tenure: $0=5$ years or less, $1=$ more than 5 years; for Operation: $0=$ China, $1=$ Malaysia. Cronbach's alpha values were presented on the diagonal line

$\dagger p<.10 ; * p<.05 ; * * p<.01 ; * * * p<.001$ 
Table 2 Results of hierarchical regression analyses for psychological contract breach, organizational cynicism, and organizational commitment components

\begin{tabular}{|c|c|c|c|c|c|c|c|c|c|c|}
\hline \multirow[t]{2}{*}{$\begin{array}{l}\text { Variable(s) } \\
\text { entered }\end{array}$} & \multicolumn{2}{|c|}{$\begin{array}{l}\text { Psychological } \\
\text { contract breach }\end{array}$} & \multicolumn{2}{|c|}{$\begin{array}{l}\text { Organizational } \\
\text { cynicism }\end{array}$} & \multicolumn{2}{|c|}{$\begin{array}{l}\text { Affective } \\
\text { commitment }\end{array}$} & \multicolumn{2}{|c|}{$\begin{array}{l}\text { Normative } \\
\text { commitment }\end{array}$} & \multicolumn{2}{|c|}{$\begin{array}{l}\text { Continuance } \\
\text { commitment }\end{array}$} \\
\hline & $\begin{array}{l}\text { Model } \\
1\end{array}$ & $\begin{array}{l}\text { Model } \\
2\end{array}$ & $\begin{array}{l}\text { Model } \\
1\end{array}$ & $\begin{array}{l}\text { Model } \\
2\end{array}$ & $\begin{array}{l}\text { Model } \\
1\end{array}$ & $\begin{array}{l}\text { Model } \\
2\end{array}$ & $\begin{array}{l}\text { Model } \\
1\end{array}$ & $\begin{array}{l}\text { Model } \\
2\end{array}$ & $\begin{array}{l}\text { Model } \\
1\end{array}$ & $\begin{array}{l}\text { Model } \\
2\end{array}$ \\
\hline Gender & .00 & .03 & -.03 & .07 & $.15 \dagger$ & .07 & $.21 *$ & .13 & $.16 \dagger$ & .08 \\
\hline Age & -.12 & -.17 & .15 & -.06 & .01 & $.20^{*}$ & -.03 & .14 & -.01 & .15 \\
\hline Tenure & .03 & .05 & -.11 & -.03 & $.21 *$ & $.13 \dagger$ & .05 & -.02 & .11 & .05 \\
\hline Operation & -.03 & .02 & -.12 & .08 & .12 & -.06 & .10 & -.07 & .09 & -.07 \\
\hline $\begin{array}{l}\text { Employee group } \\
\text { membership }\end{array}$ & & .12 & & $.47 * * *$ & & $-.43 * * *$ & & $-.39 * * *$ & & $-.36^{* *}$ \\
\hline$\Delta R^{2}$ & .01 & .01 & .04 & $.13 * * *$ & $.09 *$ & $.11 * * *$ & $.06 \dagger$ & $.09^{* * *}$ & .05 & $.08 * *$ \\
\hline
\end{tabular}

Note. For Employee group membership: $0=$ host country national, $1=$ self-initiated expatriate; for Gender: $0=$ male, $1=$ female; for Age: $0=35$ years old or less, $1=36$ years old or older; for Tenure: $0=5$ years or less, $1=$ more than 5 years; for Operation: $0=$ China, $1=$ Malaysia. Except for the $\Delta R^{2}$ row, entries are standardized regression coefficients. Final model statistics: Psychological contract breach: $F(5,146)=0.69$, $n s, R^{2}=.02$; Organizational cynicism: $F(5,139)=5.72, p<.001, R^{2}=.17$; Affective commitment: $F(5$, $141)=6.90, p<.001, R^{2}=.20$; Normative commitment: $F(5,139)=4.87, p<.001, R^{2}=.15$; Continuance commitment: $F(5,138)=3.90, p<.01, R^{2}=.12$

$\dagger p<.10 ; * p<.05 ; * * p<.01 ; * * * p<.001$

\section{Descriptive statistics and intercorrelations}

Descriptive statistics and intercorrelations are presented in Table 1. All variables displayed good internal consistency ( $\alpha \mathrm{s} \geq .88$ ). Employee group membership $(0=$ $\mathrm{HCN}, 1=\mathrm{SIE})$ was positively correlated with organizational cynicism $(r=.39, p$ $<.001$ ) and negatively correlated with affective, normative, and continuance commitment $(r \mathrm{~s}=-.38,-.32$, and -.31 , all $p<.001)$. Employee group membership was unrelated to psychological contract breach $(r=.03, n s)$. Breach was positively related to organizational cynicism $(r=.36, p<.001)$, negatively related to affective and continuance commitment $(r=-.28, p<.01$, and $r=-.27, p<.01$, respectively), and unrelated to normative commitment $(r=-.09, n s)$. Finally, organizational cynicism was negatively related to affective, normative, and continuance commitment $(r s=-.64$, -.40 , and -.38 , all $p<.001)$.

\section{Hypothesis tests}

Hypotheses 1a-e Hierarchical regression analysis was used to test Hypotheses 1a-e. Controls were entered in step 1 , while employee group membership was entered as a dichotomous variable $(0=\mathrm{HCN}, 1=\mathrm{SIE})$ in step 2 . As can be seen from Table 2 , employee group membership positively predicted organizational cynicism $(\beta=.47, p$ $<.001$ ) and negatively predicted affective, normative, and continuance commitment $(\beta \mathrm{s}=-.43,-.39$, and -.36 , all $p<.01)$. The increment in variance explained by 
Table 3 Results of moderated multiple regression analysis for organizational cynicism

\begin{tabular}{lccc}
\hline Variable(s) entered & Model 1 & Model 2 & Model 3 \\
\hline Gender & -.03 & .05 & .06 \\
Age & .15 & .01 & .01 \\
Tenure & -.11 & -.04 & -.03 \\
Operation & -.12 & .07 & .04 \\
Employee group membership & & $.42^{* * *}$ & $.42^{* * *}$ \\
Psychological contract breach & & $.33 * * *$ & .15 \\
Employee group membership $\times$ Psychological contract breach & & $.23 *$ \\
$\Delta R^{2}$ & .04 & $.24 * *$ & $.02 *$ \\
\hline
\end{tabular}

Note. For Employee group membership: $0=$ host country national, $1=$ self-initiated expatriate; for Gender: $0=$ male, $1=$ female; for Age: $0=35$ years old or less, $1=36$ years old or older; for Tenure: $0=5$ years or less, $1=$ more than 5 years; for Operation: $0=$ China, $1=$ Malaysia. Except for the $\Delta R^{2}$ row, entries are standardized regression coefficients. Final model statistics: $F(7,137)=8.31, p<.001, R^{2}=.30$

$* p<.05 ; * * * p<.001$

employee group membership was notable, varying from a low of $8 \%$ for continuance commitment to a high of $13 \%$ for organizational cynicism. Employee group membership did not significantly predict psychological contract breach $(\beta=.12, n s)$. Thus, Hypotheses 1b-e are supported while Hypothesis 1a is not supported.

Hypothesis 2 A moderated hierarchical regression analysis was conducted to test Hypothesis 2. Controls were entered in step 1, breach (centered) and employee group membership $(0=\mathrm{HCN}, 1=\mathrm{SIE})$ were entered in step 2 , and the breach $\times$ employee group membership interaction term was entered in step 3 (Aiken \& West, 1991). As can be seen from Table 3, the breach $\times$ employee group membership interaction term was significant $(\beta=.23, p<.05$; see Fig. 1 for a graphical representation). It explained $2 \%$ of unique variance in organizational cynicism, which is noteworthy in regard to sample size and previous research on dichotomous moderators (Aguinis, Beaty, Boik, \& Pierce, 2005). Simple slope analyses showed that breach was positively related to organizational cynicism among SIEs $(t[144]=4.14, p<.05)$ but not among HCNs $(t[144]=-0.01, n s)$. Moreover, these regression lines differed significantly from one another $(t[144]=2.11, p<.05)$. Hypothesis 2 is therefore supported.

Hypotheses 3a-c Bootstrap analysis was used to test Hypotheses 3a-c. We estimated the conditional indirect effect of breach on affective, normative, and continuance

\footnotetext{
${ }^{0}$ We also conducted the hypothesis tests separately for the Chinese operation and the Malaysian operation. The major difference between the results of these analyses and those obtained on the entire sample (where we controlled for the operation SIEs and HCNs were affiliated with, i.e., the Chinese operation vs. the Malaysian operation) is that, for the Chinese subsample, employee group membership (SIE vs. HCN) did not significantly predict continuance commitment $(\beta=-.22, n s)$, did not significantly interact with psychological contract breach to predict organizational cynicism $(\beta=.23, n s)$, and did not significantly moderate the indirect relationships between psychological contract breach and affective, normative, and continuance commitment, as mediated by organizational cynicism $(-.20,95 \% \mathrm{CI}[-.57, .13] ;-.10,95 \% \mathrm{CI}[-.37, .04] ;-.10,95 \% \mathrm{CI}[-.38$, $.04])$. Given the small size of the Chinese operation $(n=71)$, these non-significant results most likely reflect a lack of statistical power. This is particularly likely for the hypothesis involving moderation effects since these effects are known to be difficult to detect (Aguinis et al. 2005).
} 


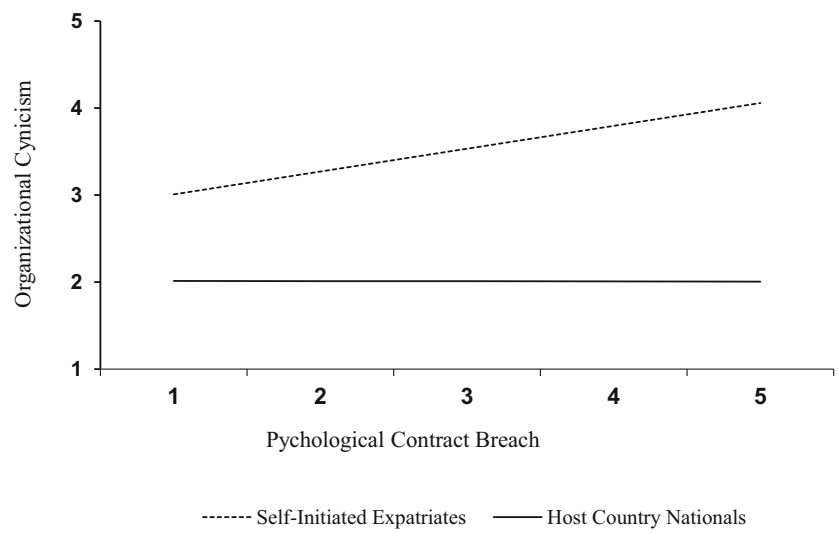

Fig. 1 Interaction between psychological contract breach and employee group membership in predicting organizational cynicism

commitment, respectively, using 5000 bootstrap resamples, and we tested its significance using bias-corrected confidence intervals (CIs; Preacher, Rucker, \& Hayes, 2007). Hayes's (2015) PROCESS macro was used to perform these analyses. Employee group membership $(0=\mathrm{HCN}, 1=\mathrm{SIE})$ was found to significantly moderate the indirect effects of breach on affective and continuance commitment, with CIs excluding zero $(-.21,95 \%$ CI $[-.44,-.00]$, and $-.11,95 \%$ CI $[-.25,-.01]$, respectively). Specifically, these effects were significantly negative among SIEs (-.31, 95\% CI $[-.48,-.17]$, and $-.16,95 \% \mathrm{CI}[-.30,-.07]$, respectively) but non-significant among HCNs $(-.10,95 \%$ CI $[-.29, .06]$, and $-.05,95 \%$ CI $[-.20, .02]$, respectively). Of interest, the $\mathrm{CI}$ for the conditional indirect effect involving normative commitment also excluded zero $(-.14,95 \%$ CI $[-.34,-.01])$. This effect was significantly negative among SIEs $(-.21,95 \% \mathrm{CI}=-.35,-.12)$ but non-significant among HCNs $(-.07$, $95 \%$ CI $[-.21, .04])$. Thus, the results of the bootstrap analysis suggested that organizational cynicism mediated the relation between psychological contract breach and affective, normative, and continuance commitment. However, recall that psychological contract breach did not significantly correlate with normative commitment $(r=-.09$, $n s$; Table 1). For this reason, we conservatively concluded that there was a significant indirect relationship between breach and normative commitment but not a mediated effect (see Holmbeck, 1997, for a similar reasoning, and MacKinnon, 2008, for a discussion). It follows that Hypotheses $3 \mathrm{a}$ and $3 \mathrm{c}$ are supported while Hypothesis $3 \mathrm{~b}$ is conservatively not supported. ${ }^{4}$

\section{Discussion}

Extending previous research (e.g., Hitotsuyanagi-Hansel et al., 2016; Makkonen, 2017), this study focused on the experience of both SIEs and HCNs. It aimed to provide a more complete and nuanced understanding of SIEs' and HCNs' experience by examining how these two groups of employees perceived and related to their organization. Relying on a sample of SIEs and HCNs from a Western organization's 
operations in the Chinese and Malaysian transnational education sector, we showed that there were significant differences between SIEs and HCNs in terms of organizational cynicism and affective, normative, and continuance commitment. We also showed that employee group membership (i.e., SIE or HCN) moderated the relationship of psychological contract breach to organizational cynicism and, indirectly, of psychological contract breach to affective and continuance commitment. Findings, theoretical implications and future research directions are discussed below.

\section{Summary of findings, theoretical implications and directions for future research}

This study found that SIEs held significantly higher levels of organizational cynicism, and significantly lower levels of affective, normative, and continuance commitment than HCNs. These findings are consistent with COR theory and may be explained by resource-related differences between these employee groups in the context of the host country and the host organization (Hobfoll, 1989). Indeed, SIEs, whose resources (e.g., tolerance of ambiguity and physical energy) are highly solicited and who do not possess certain resources needed to function effectively in the host country (e.g., local language skills, local knowledge and social networks), are more likely to experience resource depletion (Lee, 2005; Suutari \& Brewster, 2000). To protect and preserve the limited resources they possess, they should be more likely than HCNs to opt for lowresource investment coping strategies, hence show more organizational cynicism (Byrne \& Hochwarter, 2008). They should also be less likely than HCNs to invest resources in their relationship with the organization and to view it as beneficial for them, hence show less affective, normative, and continuance commitment (Meyer \& Herscovitch, 2001). Future research based on COR theory should seek to identify which critical resources may help SIEs develop more positive views of, and attitudes towards their organization. For example, McDonnell and Scullion (2013) suggest that social self-efficacy and achievement self-efficacy represent personal resources that SIEs can leverage to better adjust to the host country. It would therefore be interesting to examine if, through compensatory mechanisms, for instance, these resources help shield SIEs against organizational cynicism or build their organizational commitment. Researchers should explore these ideas in the future.

Contrary to our expectations, results suggest that SIEs and HCNs do not differ in the extent to which they perceive psychological contract breach. Still, results also show that SIEs reacted more negatively than $\mathrm{HCNs}$ to breach via increased organizational cynicism and, indirectly, lowered affective and continuance commitment. This pattern of findings indicates that the critical issue may not be the psychological contract of SIEs (vs. HCNs) or how breaches are perceived, but rather the process linking breach to its outcomes among these two groups of employees. For example, Tomprou, Rousseau, and Hansen's (2015) post-violation model suggests that the ways in which individuals cope with breach affects its relationship to work outcomes and that strategies based on withdrawal (e.g., disengagement) are particularly conducive to deleterious outcomes. Because such strategies are not costly in the short-term and involve distancing oneself from the perceived threat (Suls \& Fletcher, 1985), they should, consistent with COR theory principles (Hobfoll et al., 2018), be more prevalent among SIEs than HCNs. Future research should explore this avenue. 
In this study, we conservatively concluded that there was an indirect relationship between psychological contract breach and normative commitment but not a mediated effect, since the direct relationship between breach and normative commitment was non-significant. As suggested by Holmbeck (1997, p. 603), 'the mediator does not (and cannot) significantly "account" for the predictor-criterion relationship [in such a case] because there was not a significant relation between the predictor and the criterion in the first place'. However, MacKinnon (MacKinnon, 2008; see also Hayes, 2017) argued that mediation can exist even when the overall relationship between a predictor and a criterion is non-significant. That would be the case when, under certain circumstances, the test of the mediated effect has more statistical power than the test of the overall relationship between the predictor and the criterion (MacKinnon, 2008). By extension, moderated mediation may also exist under some circumstances. We recommend that future research continues to explore the breach-normative commitment relationship to draw firmer conclusions about the pattern of the relationship between these two variables as well as the role played by organizational cynicism and other potential mediators.

\section{Implications for practice}

This study has implications for multinational organizations and organizations that aim to attract and retain global talents. Specifically, to effectively manage different groups of employees (i.e. HCNs vs. SIEs), organizations need to address the resource challenges that they respectively face. Our research suggests that SIEs are comparatively at a higher risk of resource depletion. As shown by the findings, this might make SIEs more likely to report organizational cynicism, and less likely to report affective, normative, and continuance commitment than HCNs. SIEs might also be more likely than HCNs to become cynical toward the organization and, indirectly, to show less affective and continuance commitment toward the organization, as a result of psychological contract breach. Thus, findings suggest that SIEs primarily need to access or develop appropriate resources, i.e., resources that will help them adjust and that will promote the development of positive perceptions and attitudes among them. Given that social support and positive work relationships contribute to buffer the deleterious effects of psychological contract breach, reduce organizational cynicism, promote organizational commitment, and help with expatriates' overall adjustment (e.g., Banks et al., 2014; Caligiuri \& Lazarova, 2002; Dulac et al., 2008; Morf et al., 2019; see also Hobfoll, Freedy, Lane, \& Geller, 1990, for a discussion of COR theory and social support), organizations should aim to foster the development of supportive relationships between SIEs and other employees. For instance, to develop local network resources, gatherings could be organized between SIEs and other employees, including managers, to get them the opportunity to know each other, and interact with one another. Mentoring programs could also be established to help SIEs develop important personal resources such as self-efficacy, which is known to promote, among other things, organizational commitment and SIEs' adjustment (Lauring \& Selmer, 2014; Pillai \& Williams, 2004). Regarding HCNs, our findings suggest that they compare favorably to SIEs. Yet, this does not mean that providing appropriate resources to HCNs is not necessary. As countries such as China and Malaysia are becoming more advanced economically, HCNs are likely to be employed in increasingly important 
roles for which expatriates would have been hired in the past (Harvey et al., 2001; Toh \& DeNisi, 2007). Thus, organizations should proactively seek to do more for HCNs. Among other things, organizations should provide HCNs with career-related resources (e.g., career support and career mentoring or skill development programs), since these resources are likely to sustain positive perceptions and attitudes among them (Toh \& DeNisi, 2003).

\section{Limitations}

First, self-reports were used, and data for organizational cynicism and commitment were gathered at the same point in time, which is a limitation (Cascio, 2012). However, because all variables capture perceptual and attitudinal constructs, collecting data from third parties does not seem appropriate. Moreover, the use of a time-lagged design contributes to alleviate concerns of common method variance. Second, no detailed sociodemographic information about the participants was collected due to confidentiality constraints imposed by the participating overseas operations. For instance, we were not allowed to collect information about the country of origin of SIEs. This means that we cannot say in which proportions our sample of SIEs include parent-country nationals (PCNs) vs. third country nationals (TCNs). Because these two subgroups might differ, because most research on expatriates reports the nationality of participants (Olsen \& Martins, 2009) and because perceptions and attitudes can be shaped by sociocultural backgrounds (Waxin, 2004), future research should control for this variable. Other variables that might shape SIEs' experience such as their motivations to work in the host country or their previous work experience should also be considered as controls in future research. In the same vein, other demographics (e.g., ethnicity, organizational rank, educational level) should be included in future research. Third, due to the small sample size, we decided not to perform country comparisons in testing our main hypotheses. We controlled for location to ensure that findings do not reflect differences between countries. We also reported, in a footnote, the results of the analyses conducted separately for the Chinese and Malaysian operations. The minor differences with the results of analyses conducted on the whole sample likely reflect a lack of statistical power. Note that the above limitations about the sample are somewhat mitigated by the fact that the theoretical framework used to develop hypotheses (i.e., COR theory) does not depend on national origin but rather on employees' group membership (i.e., SIE vs. HCN). Fourth, we acknowledge that SIEs and HCNs do not represent the only groups of employees within organizations, which can be much more diverse. Organizations can also employ, for example, corporate expatriates. Although corporate expatriates did not represent a significant group of employees in the overseas operations we collaborated with, we encourage researchers to examine, in the future, differences between corporate expatriates, SIEs, HCNs, and other significant groups. Finally, we acknowledge that the modest sample size and the fact that participants were from two Asian operations of a Western organization in the transnational education sector raises questions about generalizability. Yet, it should be noted that results are rather conservative since the small sample size makes it more difficult to attain statistical significance. We also believe that the insights gained about SIEs and HCNs in this study may apply to other industries and other developing countries. In relation to the last point, we need to point out that our research follows the tradition of 
the SIE literature, which implicitly focuses on individuals who relocated from developed countries to developing countries and who do not intend to live permanently in the host country (Al Ariss, 2013). Our findings might not be generalizable to individuals who relocated from developing countries to developed countries, which are often researched by the migrant literature (Al Ariss, 2013). Replication of the findings in other samples and contexts is required.

\section{Conclusion}

This study sought to better understand the experience of SIEs vs. HCNs by relying on COR theory as a theoretical framework. We argued that, as an indication that SIEs experience more resource depletion than HCNs, SIEs would demonstrate less favorable perceptions of, and attitudes toward their organization than HCNs. Findings from a two-wave study conducted with a sample of SIEs and HCNs employed in the Chinese and Malaysian transnational education sector generally supported this proposition. SIEs reported more organizational cynicism and less affective, normative, and continuance commitment than HCNs. The indirect relation between psychological contract breach and affective and continuance commitment was also stronger among SIEs than HCNs. We hope that this study will generate interest for the study of diverse groups of employees, and help practitioners acknowledge the importance of tailoring practices to the groups' particular needs.

\section{Funding information Open Access funding provided by Norwegian Business School.}

Open Access This article is licensed under a Creative Commons Attribution 4.0 International License, which permits use, sharing, adaptation, distribution and reproduction in any medium or format, as long as you give appropriate credit to the original author(s) and the source, provide a link to the Creative Commons licence, and indicate if changes were made. The images or other third party material in this article are included in the article's Creative Commons licence, unless indicated otherwise in a credit line to the material. If material is not included in the article's Creative Commons licence and your intended use is not permitted by statutory regulation or exceeds the permitted use, you will need to obtain permission directly from the copyright holder. To view a copy of this licence, visit http://creativecommons.org/licenses/by/4.0/.

\section{References}

Abraham, R. 2000. Organizational cynicism: Bases and consequences. Genetics, Social, and General Psychology Monographs, 126(3): 269-292.

Aguinis, H., Beaty, J. C., Boik, R. J., \& Pierce, C. A. 2005. Effect size and power in assessing moderating effects of categorical variables using multiple regression: A 30-year review. Journal of Applied Psychology, 90(1): 94-107.

Aiken, L. S., \& West, S. G. 1991. Multiple regression: Testing and interpreting interactions. Thousand Oaks, CA: Sage.

Al Ariss, A. 2013. Ethnic minority migrants or self-initiated expatriates? In Andresen, M., Al Ariss, A., \& Walther, M. (Eds.) Self-initiated expatriation: Individual, organizational, and national perspectives: 235241. New York, NY. Routledge.

Altman, Y., \& Baruch, Y. 2013. Global self-initiated corporate careerists: What drives them and implications for HRM. In V. Vaiman, \& A. Haslberger (Eds.). Talent management of self-initiated expatriates: 19-29. London, UK: Palgrave Macmillan. 
Andersen, N. 2019. Mapping the expatriate literature: A bibliometric review of the field from 1998 to 2017 and identification of current research fronts. International Journal of Human Resource Management. Advance online publication. https://doi.org/10.1080/09585192.2019.1661267

Andersson, L. M. 1996. Employee cynicism: An examination using a contract violation framework. Human Relations, 49(11): 1395-1418.

Bal, P. M., De Lange, A. H., Jansen, P. G. W., \& Van Der Velde, M. E. G. 2008. Psychological contract breach and job attitudes: A meta-analysis of age as a moderator. Journal of Vocational Behavior, 72(1): $143-158$.

Banks, G. C., Batchelor, J. H., Seers, A., O'Boyle Jr, E. H., Pollack, J. M., \& Gower, K. 2014. What does team-member exchange bring to the party? A meta-analytic review of team and leader social exchange. Journal of Organizational Behavior, 35(2): 273-295.

Bentein, K., Vandenberg, R. J., Vandenberghe, C., \& Stinglhamber, F. 2005. The role of change in the relationship between commitment and turnover: A latent growth modeling approach. Journal of Applied Psychology, 90(3): 468-482.

Bhaskar-Shrinivas, P., Harrison, D. A., Shaffer, M., \& Luk, D. M. 2005. Input-based and time-based models of international adjustment: Meta-analytic evidence and theoretical extensions. Academy of Management Journal, 48(2): 257-281.

Brookfield Global Relocation Services. 2016. 2016 Global mobility trends survey. http://globalmobilitytrends. bgrs.com/, .

Byrne, Z. S., \& Hochwarter, W. A. 2008. Perceived organizational support and performance: Relationships across levels of organizational cynicism. Journal of Managerial Psychology, 23(1): 54-72.

Caligiuri, P. M., \& Lazarova, M. B. 2002. A model for the influence of social interaction and social support on female expatriates' cross-cultural adjustment. International Journal of Human Resource Management, 13(5): 761-772.

Cascio, W. F. 2012. Methodological issues in international HR management research. International Journal of Human Resource Management, 23(12): 2532-2545.

Chen, F., Curran, P. J., Bollen, K. A., Kirby, J., \& Paxton, P. 2008. An empirical evaluation of the use of fixed cutoff points in RMSEA test statistic in structural equation models. Sociological Methods \& Research, 36(4): 462-494.

Chen, Y. P., \& Shaffer, M. A. 2017. The influences of perceived organizational support and motivation on self-initiated expatriates' organizational and community embeddedness. Journal of World Business, 52(2): 197-208.

Collings, D. G., Scullion, H., \& Morley, M. J. 2007. Changing patterns of global staffing in the multinational enterprise: Challenges to the conventional expatriate assignment and emerging alternatives. Journal of World Business, 42(2): 198-213.

Conway, N., Guest, D., \& Trenberth, L. 2011. Testing the differential effects of changes in psychological contract breach and fulfillment. Journal of Vocational Behavior, 79(1): 267-276.

Coyle-Shapiro, J. A. M., Costa, S. P., Doden, W., \& Chang, C. 2019. Psychological contracts: Past, present, and future. Annual Review of Organizational Psychology and Organizational Behavior, 6(1), 145-169.

Crawford, E. R., LePine, J. A., \& Rich, B. L. 2010. Linking job demands and resources to employee engagement and burnout: A theoretical extension and meta-analytic test. Journal of Applied Psychology, 95(5): 834-848.

Dean, J. W., Brandes, P., \& Dharwadkar, R. 1998. Organizational cynicism. Academy of Management Review, 23(2): 341-352.

Dowling, P., Festing, M., \& Engle, A. 2008. International human resource management: Managing people in a multinational context. Melbourne, Australia: Tomsons.

Dulac, T., Coyle-Shapiro, J. A.-M., Henderson, D. J., \& Wayne, S. J. 2008. Not all responses to breach are the same: The interconnection of social exchange and psychological contract processes in organizations. Academy of Management Journal, 51(6): 1079-1098.

Froese, F. J. 2012. Motivation and adjustment of self-initiated expatriates: The case of expatriate academics in South Korea. International Journal of Human Resource Management, 23(6): 1095-1112.

Gkorezis, P., Georgiou, L., \& Theodorou, M. 2018. High-performance work practices and nurses' intention to leave: The mediating role of organizational cynicism and the moderating role of human resource management-related educational background. International Journal of Human Resource Management, 29(3): 465-484.

Goodman, J. S., \& Blum, T. C. 1996. Assessing the non-random sampling effects of subject attrition in longitudinal research. Journal of Management, 22(4): 627-652. 
Halbesleben, J. R. B., Harvey, J. \& Bolino, M. C. 2009. Too engaged? A conservation of resources view of the relationship between work engagement and work interference with family. Journal of Applied Psychology, 94(6): 1452-1465.

Halbesleben, J. B. R., Neveu, J. P., Paustian-Underdahl, S. C., \& Westman, M. 2014. Getting to the "COR": Understanding the role of resources in conservation of resources theory. Journal of Management, 40(5): 1334-1364.

Halim, H., Bakar, H. A., \& Mohamad, B. 2014. Expatriate adjustment: Validating multicultural personality trait among self-initiated academic expatriates. Procedia - Social and Behavioral Sciences, 155: 123-129.

Harvey, M., Speier, C., \& Novecevic, M. M. 2001. A theory-based framework for strategic global human resource staffing policies and practices. International Journal of Human Resource Management, 12(6): 898-915.

Haslberger, A., \& Vaiman, V. 2013. Self-initiated expatriates: A neglected source of the global talent flow. In V. Vaiman, \& A. Haslberger (Eds.). Talent management of self-initiated expatriates: 1-15. London, UK: Palgrave Macmillan.

Hassan, A., \& Hashim, J. 2011. Role of organizational justice in determining work outcomes of national and expatriate academic staff in Malaysia. International Journal of Commerce and Management, 21(1): 8293.

Hayes, A. F. 2015. An index and test of linear moderated mediation. Multivariate Behavioral Research, 50(1): $1-22$.

Hayes, A. F. 2017. Introduction to mediation, moderation, and conditional process analysis: A regressionbased approach. New York, NY: Guilford.

Hitotsuyanagi-Hansel, A., Froese, F. J., \& Pak, Y. S. 2016. Lessening the divide in foreign subsidiaries: The influence of localization on the organizational commitment and turnover intention of host country nationals. International Business Review, 25(2): 569-578.

Hobfoll, S. E. 1989. Conservation of resources: A new attempt at conceptualizing stress. American Psychologist, 44(3): 513-524.

Hobfoll, S. E., Freedy, J., Lane, C., \& Geller, P. 1990. Conservation of social resources: Social support resource theory. Journal of Social and Personal Relationships, 7(4): 465-478.

Hobfoll, S. E., Halbesleben, J., Neveu, J. P., \& Westman, M. 2018. Conservation of resources in the organizational context: The reality of resources and their consequences. Annual Review of Organizational Psychology and Organizational Behavior, 5(1): 103-128.

Hobfoll, S. E., \& Shirom, A. 2001. Conservation of resources theory: Applications to stress and management in the workplace. In R. T. Golembiewski (Ed.). Handbook of organizational behavior: pp. 57-80. New York, NY: Marcel Dekker.

Holmbeck G. N. 1997. Toward terminological, conceptual, and statistical clarity in the study of mediators and moderators: Examples from the child-clinical and pediatric psychology literatures. Journal of Consulting and Clinical Psychology, 65(4): 599-610.

Hu, L.-T., \& Bentler, P. M. 1999. Cutoff criteria for fit indexes in covariance structure analysis: Conventional criteria versus new alternatives. Structural Equation Modeling, 6(1): 1-55.

Johnson, J. L., \& O'Leary-Kelly, A. M. 2003. The effects of psychological contract breach and organizational cynicism: Not all social exchange violations are created equal. Journal of Organizational Behavior, 24(5): 627-647.

Kenny, D. A., Kaniskan, B., \& McCoach, D. B. 2015. The performance of RMSEA in models with small degrees of freedom. Sociological Methods \& Research, 44(3): 486-507.

Kiazad, K., Seibert, S. E., \& Kraimer, M. L. 2014. Psychological contract breach and employee innovation: A conservation of resources perspective. Journal of Occupational and Organizational Psychology, 87(3): 535-556.

Kraimer, M., Bolino, M., \& Mead, B. 2016. Themes in expatriate and repatriate research over four decades: What do we know and what do we still need to learn? Annual Review of Organizational Psychology and Organizational Behavior, 3(1): 83-109.

Kraimer, M. L., Takeuchi, R., \& Frese, M. 2014. The global context and people at work: Special issue introduction. Personnel Psychology, 67(1): 5-21.

Kraimer, M. L., Wayne, S. J., \& Jaworski, R. A. 2001. Sources of support and expatriate performance: The mediating role of expatriate adjustment. Personnel Psychology, 54(1): 71-99.

Lapointe, E., Vandenberghe, C., \& Boudrias, S. 2013. Psychological contract breach, affective commitment to organization and supervisor, and newcomer adjustment: A three-wave moderated mediation model. Journal of Vocational Behavior, 83(3): 528-538. 
Lapointe, E., Vandenberghe, C., \& Panaccio, A. 2011. Organizational commitment, organization-based selfesteem, emotional exhaustion and turnover: A conservation of resources perspective. Human Relations, 64(12): 1609-1631.

Lauring, J., \& Selmer, J. 2014. Global mobility orientation and the success of self-initiated expatriates in greater China. Asia Pacific Business Review, 20(4): 523-540.

Lazarova, M., Westman, M., \& Shaffer, M. A. 2010. Elucidating the positive side of the work-family interface on international assignments: A model of expatriate work and family performance. Academy of Management Review, 35(1): 93-117.

Lee, C. H. 2005. A study of underemployment among self-initiated expatriates. Journal of World Business, 40(2): 172-187.

Lorinkova, N. M., \& Perry, S. J. 2017. When is empowerment effective? The role of leader-leader exchange in empowering leadership, cynicism, and time theft. Journal of Management, 43(5): 1631-1654.

MacKinnon, D. P. 2008. Introduction to statistical mediation analysis. Mahwah, NJ: Erlbaum.

Makkonen, P. 2016. Career self-management behaviour of Western self-initiated expatriates in local organizations in China. International Journal of Human Resource Management, 27(11): 1135-1157.

Makkonen, P. 2017. The employability of newcomer self-initiated expatriates in China: An employers' perspective. Asia Pacific Journal of Human Resources, 55(4): 498-515.

Mayo, M., \& Mallin, M. L. 2010. The impact of sales failure on attributions made by "resource-challenged" and "resource-secure" salespeople. Journal of Marketing Theory \& Practice, 18(3): 233-247.

McDonnell, A., \& Scullion, H. 2013. Self-initiated expatriate's adjustment: A neglected terrain. In V. Vaiman, \& A. Haslberger (Eds.). Talent management of self-initiated expatriates: 136-155. London, UK: Palgrave Macmillan.

McNulty, Y. 2013. Are self-initiated expatriates born or made? Exploring the relationship between SIE orientation and individual ROI. In V. Vaiman, \& A. Haslberger (Eds.). Talent management of selfinitiated expatriates: 30-58. London, UK: Palgrave Macmillan.

Meyer, J. P., \& Allen, N. J. 1991. A three-component conceptualization of organizational commitment. Human Resource Management Review, 1(1): 61-89.

Meyer, J. P., Allen, N. J., \& Smith, C. A. 1993. Commitment to organizations and occupations: Extension and test of a three-component conceptualization. Journal of Applied Psychology, 78(4): 538-551.

Meyer, J. P., \& Herscovitch, L. 2001. Commitment in the workplace: Toward a general model. Human Resource Management Review, 11(3): 299-326.

Meyer, J. P., Stanley, D. J., Herscovitch, L., \& Topolnytsky, L. 2002. Affective, continuance, and normative commitment to the organization: A meta-analysis of antecedents, correlates, and consequences. Journal of Vocational Behavior, 61(1): 20-52.

Morf, M., Bakker, A. B., \& Feierabend, A. 2019. Bankers closing idiosyncratic deals: Implications for organisational cynicism. Human Resource Management Journal, 29(4): 585-599.

Morrison, E. W., \& Robinson, S. L. 1997. When employees feel betrayed: A model of how psychological contract violation develops. Academy of Management Review, 22(1): 226-256.

Muthen, L. K., \& Muthen, B. O. 2011. MPLUS (version 6.12) [computer software]. Los Angeles, CA: Muthen \& Muthen.

O’Donohue, W., Hutchings, K., \& Hansen, S. D. 2018. Psychological contracts: Enhancing understanding of the expatriation experience. International Journal of Human Resource Management, 29(8): 1379-1401.

Olsen, J. E., \& Martins, L. L. 2009. The effects of expatriate demographic characteristics on adjustment: A social identity approach. Human Resource Management, 48(2): 311-328.

Parzefall, M-R., \& Coyle-Shapiro, J. A.-M. 2011. Making sense of psychological contract breach. Journal of Managerial Psychology, 26(1): 12-27.

Perera, H. K., Chew, E. Y. T., \& Nielsen, I. 2017. A psychological contract perspective of expatriate failure. Human Resource Management, 56(3): 479-499.

Pfrombeck, J., Doden, W., Grote, G., \& Feierabend, A. 2020. A study of organizational cynicism and how it is affected by social exchange relationships at work. Journal of Occupational and Organizational Psychology. Advanced online publication. https://doi.org/10.1111/joop.12306

Pillai, R., \& Williams, E. A. 2004. Transformational leadership, self-efficacy, group cohesiveness, commitment, and performance. Journal of Organizational Change Management, 17(2): 144-159.

Powell, D. M., \& Meyer, J. P. 2004. Side-bet theory and the three-component model of organizational commitment. Journal of Vocational Behavior, 65(1): 157-177.

Preacher, K. J., Rucker, D. D., \& Hayes, A. F. 2007. Addressing moderated mediation hypotheses: Theory, methods, and prescriptions. Multivariate Behavioral Research, 42(1): 185-227.

Ramalu, S. S., Subramaniam, C., \& Nadarajah, G. 2017. Self-initiated expatriate academic performance in Malaysian universities. International Journal of Business \& Management Science, 7(2): 171-194. 
Reiche, B. S. 2007. The effect of international staffing practices on subsidiary staff retention in multinational corporations. International Journal of Human Resource Management, 18(4): 523-536.

Richards, D. 1996. Strangers in a strange land: Expatriate paranoia and the dynamics of exclusion. International Journal of Human Resource Management, 7(2): 553-571.

Richardson, C., \& Ng, K. H. 2019. No place like home? Self-initiated expatriates in their ancestral homeland. Asia Pacific Journal of Human Resources. Advance online publication. https://doi.org/10.1111/17447941.12242

Richardson, C., \& Wong, H.-W. 2018. Expatriate academics in Malaysia: Motivation, adjustment, and retention. Journal of Management Development, 37(3): 299-308.

Robinson, S. L., \& Morrison, E. W. 2000. The development of psychological contract breach and violation: A longitudinal study. Journal of Organizational Behavior, 21(5): 526-546.

Rousseau, D. M., Hansen, S. D., \& Tomprou, M. 2018. A dynamic phase model of psychological contract processes. Journal of Organizational Behavior, 39(9): 1081-1098.

Selmer, J., Andersen, M., \& Cerdin, J.-L. 2017. Self-initiated expatriates. In Y. McNulty, \& J. Selmer (Eds.). Research handbook of expatriates: 187-201. Cheltenham, UK: Edward Elgar.

Selmer, J., \& Lauring, J. 2014. Self-initiated expatriates: An exploratory study of adjustment of adult thirdculture kids vs. adult mono-culture kids. Cross Cultural Management: An International Journal, 21(4): 422-436.

Shaffer, M. A., \& Harrison, D. A. 1998. Expatriates' psychological withdrawal from international assignments: Work, non-work and family influences. Personnel Psychology, 51(1): 87-118.

Shaffer, M. A., Kraimer, M. L., Chen, Y.-P., \& Bolino, M. C. 2012. Choices, challenges, and career consequences of global work experiences. Journal of Management, 38(4): 1282-1327.

Shen, Y., \& Kram, K. E. 2011. Expatriates' developmental networks: Network diversity, base, and support functions. Career Development International, 16(6): 528-552.

Singh, S. K., Pereira, V. E., Mellahi, K., \& Collings, D. G. 2019. Host country nationals characteristics and willingness to help self-initiated expatriates in the UAE. International Journal of Human Resource Management. Advance online publication. https://doi.org/10.1080/09585192.2018.1547778

Suls, J., \& Fletcher, B. 1985. The relative efficacy of avoidant and non-avoidant coping strategies: A metaanalysis. Health Psychology, 4(3): 249-288.

Suutari, V., \& Brewster, C. 2000. Making their own way: International experience through self-initiated foreign assignments. Journal of World Business, 35(4): 417-436.

Suutari, V., Brewster, C., Makela, L., Dickmann, M., \& Tornikoski, C. 2018. The effect of international work experience on the career success of expatriates: A comparison of assigned and self-initiated expatriates. Human Resource Management, 57(1): 37-54.

Tang, A. D., Chang, M.-L., \& Cheng, C.-F. 2017. Enhancing knowledge sharing from self-initiated expatriates in Vietnam: The role of internal marketing and work-role adjustment in an emerging economy. Asia Pacific Business Review, 23(5): 677-696.

Tarique, I., Schuler, R., \& Gong, Y. 2006. A model of multinational enterprise subsidiary staffing composition. International Journal of Human Resource Management, 17(2): 207-224.

Taylor, S. E., \& Fiske, S. T. 1978. Salience, attention, and attribution: Top of the head phenomena. In L. Berkowitz (Ed.). Advances in experimental social psychology, vol. 11: 249-288. New York, NY: Academic Press.

Ten Brummelhuis, L. L., \& Bakker, A. B. 2012. A resource perspective on the work-home interface: The work-home resources model. American Psychologist, 67(7): 545-556.

Tharenou, P. 2013. Self-initiated expatriates: An alternative to company-assigned expatriates? Journal of Global Mobility, 1(3): 336-356.

Tharenou, P. 2015. Researching expatriate types: The quest for rigorous methodological approaches. Human Resource Management Journal, 25(2): 149-165.

Toh, S. M., \& DeNisi, A. S. 2003. Host country national $(\mathrm{HCN})$ reactions to expatriate pay policies: A proposed model and some implications. Academy of Management Review, 28(4): 606-621.

Toh, S. M., \& DeNisi, A. S. 2007. Host country nationals as socializing agents: A social identity approach. Journal of Organizational Behavior, 28(3): 281-301.

Tomprou, M., Rousseau, D. M., \& Hansen, S. D. 2015. The psychological contracts of violation victims: A post-violation model. Journal of Organizational Behavior, 36(4): 561-581.

Vance, C. M., Vaiman, V., \& Andersen, T. 2009. The vital liaison role of host country nationals in MNC knowledge management. Human Resource Management, 48(4): 649-659.

Vandenberghe, C., Panaccio, A., \& Ben Ayed, A. K. 2011. Continuance commitment and turnover: Examining the moderating role of negative affectivity and risk aversion. Journal of Occupational and Organizational Psychology, 84(2): 403-424. 
Waxin, M. F. 2004. Expatriates' interaction adjustment: The direct and moderator effects of culture of origin. International Journal of Intercultural Relations, 28(1): 61-79.

Wilkerson, J. M., Evans, W. R., \& Davis, W. D. 2008. A test of coworkers' influence on organizational cynicism, badmouthing, and organizational citizenship behavior. Journal of Applied Social Psychology, 38(9): 2273-2292.

Wong, P., \& Weiner, B. 1981. When people ask "why" questions, and the heuristics of attributional search. Journal of Personality and Social Psychology, 40(4): 650-663.

Yang, Z., Wang, X., \& Su, S. 2006. A review of research methodologies in international business. International Business Review, 15(6): 601-617.

Yeung, A., Warner, M., \& Rowley, C. 2008. Growth and globalization: Evolution of human resource management practices in Asia. Human Resource Management, 47(1): 1-13.

Zhu, J., Wanberg, C. R., Harrison, D. A., \& Diehn, E. W. 2016. Ups and downs of the expatriate experience? Understanding work adjustment trajectories and career outcomes. Journal of Applied Psychology, 101(4): 549-568.

Publisher's note Springer Nature remains neutral with regard to jurisdictional claims in published maps and institutional affiliations.

Émilie Lapointe ( $\mathrm{PhD}$, Université de Montréal) is an Associate Professor in the Department of Leadership and Organizational Behavior, BI Norwegian Business School. Her current research is in the areas of organizational socialization, employee-supervisor relationships, employee-organization relationships, and international organizational behavior and human resource management. She has published academic articles in journals such as Human Relations, Journal of Vocational Behavior, Journal of Occupational and Organizational Psychology, Asia Pacific Journal of Management, and International Journal of Human Resource Management, and international conference papers.

Christian Vandenberghe ( $\mathrm{PhD}$, Université catholique de Louvain) is a Professor of Organizational Behavior at HEC Montréal and holder of the Research Chair in management of employee commitment and performance. His research interests include organizational commitment, turnover and performance, and attitude change. His work has been published in a variety of journals, including Journal of Applied Psychology, Journal of Management, Journal of Organizational Behavior, Human Relations, Entrepreneurship Theory and Practice, Human Resource Management, Journal of Occupational and Organizational Psychology, Journal of Vocational Behavior, and Group \& Organization Management.

Shea X. Fan (PhD, University of Melbourne) is Senior Lecturer of International Business at RMIT University, Australia. Dr. Fan's key research interests include cross-cultural management and international management, with a special focus on an identity perspective. Shea has published in Human Resource Management, the Journal of World Business, Applied Psychology: An International Review, and the International Journal of Human Resource Management.

\section{Affiliations}

\section{Émilie Lapointe $^{1} \cdot$ Christian Vandenberghe $^{2} \cdot$ Shea X. Fan $^{3}$}

1 Department of Leadership and Organizational Behaviour, BI Norwegian Business School, Nydalsveien 37, 0484 Oslo, Norway

2 Department of Management, HEC Montréal, 3000 Chemin de la Côte Sainte-Catherine, Montréal, Québec H3T 2A7, Canada

3 School of Management, RMIT University, Level 9, Building 80, 445 Swanston Street, Melbourne, VIC 3000, Australia 